\title{
Effects of Oxytetracycline on Growth and Chlorophyll Fluorescence in Rape (Brassica campestris L.)
}

\author{
Yansong Chen ${ }^{1,2 *}$, Zhanjun Wang ${ }^{2}$, Zhangjun Shen ${ }^{2}$, Zulan $\mathrm{Ou}^{2}$, \\ Decong $\mathrm{Xu}^{2}$, Zhuxia Yuan ${ }^{2}$, Shoubiao Zhou ${ }^{1 * *}$ \\ ${ }^{1}$ Anhui Provincial Key Laboratory of the Conservation and Exploitation of Biological Resources, \\ Anhui Normal University, Wuhu, Anhui 241000, China \\ ${ }^{2}$ School of Life Sciences, Hefei Normal University, Hefei, Anhui 230601, China
}

Received: 11 October 2016

Accepted: 6 December 2016

\begin{abstract}
This study aims to investigate the effects of oxytetracycline on growth and photosynthetic capacity of rape (Brassica campestris L.). Four levels of oxytetracycline $\left(0,10,100\right.$, and $\left.200 \mathrm{mg} \mathrm{kg}^{-1}\right)$ were added to the potted soil. Chlorophyll fluorescence parameters induced by five levels (90, 190, 420, 820, and $1,500 \mu \mathrm{mol}$ photons $\mathrm{m}^{-2} \mathrm{~s}^{-1}$ ) of PAR (PAR, photosynthetically active radiation) were measured. Plant growth indices and leaf traits were also determined. Electron transport rate increased along with the increase of PAR, but an opposite trend was found for the effective quantum yield of PSII. The quantum yield of light-induced non-photochemical fluorescence quenching in higher oxytetracycline treatments (100 and $200 \mathrm{mg} \mathrm{kg}^{-1}$ ) gradually increased when PAR increased from 90 to $820 \mu \mathrm{mol}$ photons $\mathrm{m}^{-2} \mathrm{~s}^{-1}$, but then declined under higher PAR gradients. The fractions of quantum yield of non-light-induced non-photochemical fluorescence quenching in PSII were significantly higher in all the oxytetracycline treatments than in the control. Oxytetracycline exposure was also found to alter the energy distribution in the photosynthetic electron transport chain. This study showed that oxytetracycline exposure evidently diminished the photosynthetic capacity of rape, which was further supported by the observations that growth indices and leaf traits were significantly inhibited by oxytetracycline.
\end{abstract}

Keywords: oxytetracycline, chlorophyll fluorescence, rape, soil pollution, growth

\section{Introduction}

Antibiotics, widely used by people or livestock to cure disease, are often excreted directly in original chemical

*e-mail: ottffss7531 cn@126.com

**e-mail: zhoushoubiao@vip.163.com form through urine and feces [1]. Antibiotics can persist in the environment owing to their stable physical and chemical properties. The accumulation rate of residual antibiotics has gradually exceeded the degradation rate in soil [2], which may cause indisputable environmental pollution [3]. For decades, various residual antibiotics were detected in different environmental and plant samples, including soil, surface water, underground 
drainage, groundwater, air, food crops (such as wheat), and vegetables [4-6]. It has been a growing issue that plants, animals, and microbes are facing risk of exposure to antibiotics with low doses for long-term and even the whole life history in an ecosystem [7-8]. Antibiotics are an emerging kind of pollutant in soil, which recently has received growing concern in the research field of ecotoxicology.

Tetracyclines are a class of broad-spectrum antibiotics used by humans and animals with the highest consumption in the world. The accumulation of tetracyclines in farmland through the application of manure is increasing annually. In Europe, the value of tetracycline concentration in samples of pig manure was $<46 \mathrm{mg} \mathrm{kg}^{-1}$ [9]. Average contents of tetracycline within $0-10 \mathrm{~cm}$ soil layer from Germany farmland and meadow were $4 \mathrm{mg}$ $\mathrm{kg}^{-1}$ and $0.86 \mathrm{mg} \mathrm{kg}^{-1}$, respectively [10]. The detection rate of oxytetracycline was the highest of the tetracycline antibiotics in China [11]. The range of tetracycline concentration in pig manure samples was $1-100 \mathrm{mg} \mathrm{kg}^{-1}$ in China [12]. Similarly, residual tetracycline content in farmland soil was detected as $2.669 \mathrm{mg} \mathrm{kg}^{-1}$ in the eastern region of China [13]. The highest concentration of residual oxytetracycline in $0-40 \mathrm{~cm}$ soil due to fertilization with animal excreta was $2.683 \mathrm{mg} \mathrm{kg}^{-1}$ in northern China, and the maximum concentration reached $183.50 \mathrm{mg} \mathrm{kg}^{-1}$ in animal manure [14].

Residual oxytetracycline in soil has effects of acute or chronic toxicity on organisms [15]. It is well known that tetracyclines in soil can affect plant growth and photosynthesis capacity of Phaseolus vulgaris [16], Oryza sativa [17], Triticum aestivum [18], and Iberis sempervirens [19]. Certain ecological toxicity of the tetracyclines on plant roots, stems, and leaves were also confirmed with some hydroponic research [20]. Recently, research has focused on understanding and defining the ecological toxicity of tetracyclines on crops.

Brassica campestris "Zheshuang 72" is an excellent cultivar of rape widely planted in eastern China. The growth of such a crop being threatened by oxytetracycline is increasing. So far, studies of rape have focused mainly on crop cultivation [21], bioenergetics [22], genetics and breeding science [23-24], and genomics [25-26]. Recently, various pollutants such as ozone and heavy metals and their effect on rape have been investigated in many reports [27-30]. However, little is known about the ecological toxicity of soil oxytetracycline on rape [31].

Photosynthesis is an important biochemical process that converts light energy into chemical energy. Chlorophyll fluorescence produced by the PSII reaction center in plant leaves is closely related to the process of photosynthesis reaction. In general, the fraction of energy dissipation through producing chlorophyll fluorescence is very slight [32]. It is well known that there are mainly three allocation paths of light energy captured by the PSII reaction center: (1) to drive the electrons from the reaction center $P_{680}$ to $\mathrm{Q}_{\mathrm{A}}$ represented by effective quantum yield of photosystem II $\left(\Phi_{\mathrm{PSII}}\right) ;(2)$ light-induced non-photochemical quenching $\left(\Phi_{\mathrm{NPQ}}\right)$; and (3) non-light-induced non-photochemical quenching $\left(\Phi_{\mathrm{NO}}\right)$ [33-35]. There is a dynamic equilibrium under different photosynthetically active radiation (PAR) conditions, and the balance equation is shown as $\Phi_{\mathrm{PSII}}+\Phi_{\mathrm{NPQ}}+\Phi_{\mathrm{NO}}=1$. Chlorophyll fluorescence is a rapid, and non-traumatic probe to study the photosynthetic capacity of plants [36-37]. It is also a useful technique for revealing the photosynthetic physiological law of plants in adversity. At present, chlorophyll fluorescence induction kinetics curve analysis has been extensively used to assess the photosynthetic system status of plants growing under adverse environments from the perspective of energy allocation and balance [38]. Some studies have revealed that antibiotics can have ecotoxicological impacts on the photosynthesis of photosynthetic organisms [39-40].

Overall, it is urgent that we explore the potential ecological toxicity of oxytetracycline on Zheshuang 72 as it relates to photosynthesis. In this study, we attempt 1) to unseal the growth characteristics of rape affected by oxytetracycline content in soil, 2) to disclose the features of energy distribution in the photosynthetic electron transport chain in leaves of rape under oxytetracycline exposure, and 3) to evaluate the ecotoxicity of the oxytetracycline on rape with the characteristics of photosynthetic activity and photo-protective capacity. The results will be helpful for understanding the ecotoxicology of environmental antibiotics on profitable crops.

\section{Material and Methods}

\section{Exposure Assays}

Oxytetracycline hydrochloride $(\geq 98.9 \%$ purity, standard grade, Merck \& Co., Inc., Germany) was purchased from Hefei Meifeng Chemical Ltd. Co. (Hefei, China). Zheshuang 72 was purchased in a local seed market in Hefei. First of all, we cultured the seedlings of rape to draw out the first true leaf for potting. The air-dried soil samples were sieved through a 4-mm mesh sieve and placed into plastic pots with an upper diameter of $22.0 \mathrm{~cm}$, a lower diameter of $18.0 \mathrm{~cm}$, and a depth of $20.0 \mathrm{~cm}$, and each pot was filled with about $3.5 \mathrm{~kg}$ soil mixed uniformly with the specified content of the oxytetracycline. Four level contents of the oxytetracycline were $0,10,100$, and $200 \mathrm{mg} \mathrm{kg}^{-1}$ marked with $\mathrm{CK}$, $\mathrm{A}, \mathrm{B}$, and $\mathrm{C}$, respectively. The bulk density of soil is $0.87 \mathrm{~g} \mathrm{~cm}^{-3}$, and available $\mathrm{N}, \mathrm{P}, \mathrm{K}$, and organic matter content were $39.22 \mathrm{mg} \mathrm{kg}^{-1}, 16.41 \mathrm{mg} \mathrm{kg}^{-1}$, $41.73 \mathrm{mg} \mathrm{kg}^{-1}$, and $22.28 \mathrm{~g} \mathrm{~kg}^{-1}$, respectively. Three seedlings of rape with similar size were randomly allocated into each pot. Each treatment was replicated three times in an artificial climate chamber at Hefei Normal University (13 h light, $25^{\circ} \mathrm{C}$, per day) with PAR of $200 \mu \mathrm{mol}$ photons $\mathrm{m}^{-2} \mathrm{~s}^{-1}$ and relative humidity of $55-65 \%$. The plants were watered every day to keep the soil moist. Cultivation experiments were conducted from 1 December 2015 to 1 March 2016, and the following parameters/indices were determined at the end of the cultivation phase. 


\section{Plant Growth Parameter Measurements}

After non-traumatic leaf traits determination and Fluorescence induction kinetics curve analysis, total biomass for each plant, including roots, stems, and leaves, was weighed with an electronic balance after drying at $80^{\circ} \mathrm{C}$ for $48 \mathrm{~h}(n=9$ for each treatment), and the number of rape nodes of each plant under different treatments was counted ( $n=9$ for each treatment).

\section{Leaf Traits Determination}

In order to ensure the comparability of the data, we analyzed the third fully expanded leaf from the upper end of each plant under each of four treatments to be the measurement unit in this paper $(n=9)$. The leaves were traced for leaf traits determination.

First, after fully dark adapted for $10 \mathrm{~h}$, potential photosynthetical capacity represented as maximum quantum yield $(F v / F m)$ of PSII in leaf was measured with a portable Junior-PAM (Walz, Germany), which applies a modulated blue light (LED-lamp peaking at $450 \mathrm{~nm}$ ) as a source for measuring actinic and saturating light. Each target leaf was fixed in a magnetic leaf clip and kept at a distance of $1 \mathrm{~mm}$ from leaf surface to the tip of the $1.5 \mathrm{~mm}$-diameter plastic fiber optics. The value of $F_{\mathrm{v}} / F_{\mathrm{m}}$ was calculated from the equation:

$$
F_{\mathrm{v}} / F_{\mathrm{m}}=\left(F_{\mathrm{m}}-F_{\mathrm{o}}\right) / F_{\mathrm{m}}
$$

$\ldots$ where $F_{\mathrm{o}}, F_{\mathrm{m}}$, and $F_{\mathrm{v}}$ are initial, maximum, and variable chlorophyll fluorescence, respectively. $F_{0}$ was assessed with a weak modulated pulse $\left(5 \mu \mathrm{mol}\right.$ photons $\left.\mathrm{m}^{-2} \mathrm{~s}^{-1}\right)$, and $F_{\mathrm{m}}$, corresponding to all PSII centers in the closed state, was induced by a $0.7 \mathrm{~s}$ pulse of saturating modulated blue light $\left(10,000 \mu \mathrm{mol}\right.$ photons $\left.\mathrm{m}^{-2} \mathrm{~s}^{-1}\right)$.

Next, relative chlorophyll content of leaf (represented as SPAD) was determined using a SPAD-502 Plus chlorophyll meter (Minolta Japan, Konica). SPAD readings provide a noninvasive surrogate method for surveying leaf chlorophyll concentration [41]. The average of three SPAD readings for each leaf was recorded. Finally, leaf length and leaf width were determined with a digital vernier caliper.

\section{Fluorescence Induction Kinetics Curve Analysis}

The above leaves were also traced for chlorophyll fluorescence measurements $(n=9)$. Chlorophyll fluorescence induction kinetics curve analysis was also performed with the portable Junior-PAM. For each leaf, electron transport rate $(E T R)$, effective quantum yield of photosystem II $\left(\Phi_{\mathrm{PSII}}\right)$, quantum yield of light-induced non-photochemical fluorescence quenching $\left(\Phi_{\mathrm{NPQ}}\right)$, and quantum yield of non-light induced non-photochemical fluorescence quenching $\left(\Phi_{\mathrm{NO}}\right)$ were determined under five levels of actinic light (PAR $=90,190,420,820$, and $1,500 \mu \mathrm{mol}$ photons $\mathrm{m}^{-2} \mathrm{~s}^{-1}$ ) with an initial measuring procedure of instrument from 08:30 to 11:30. The value of $\Phi_{\text {PSII }}$ at each PAR gradient was calculated from the equation:

$$
\Phi_{\mathrm{PSII}}=\left(F_{\mathrm{m}}{ }^{\prime}-F\right) / F_{\mathrm{m}}{ }^{\prime}
$$

...where $F$ is the fluorescence yield in real time and $F_{\mathrm{m}}{ }^{\prime}$ is the maximum fluorescence yield of a certain actinic light-adapted leaf. ETR was calculated as:

$$
\Phi_{\mathrm{PSII}} \times \mathrm{PAR} \times a \times b
$$

... where $a=0.84$ is the leaf absorbance and $b=0.5$ reflects the fraction of photons absorbed by PSII [35]. The values of $\Phi_{\mathrm{NPQ}}$ and $\Phi_{\mathrm{NO}}$ were calculated according to Kramer et al. [34].

In addition, the values of $F v / F m, E T R, \Phi_{\text {PSII }}$, and $\Phi_{\mathrm{NPQ}}$ were calculated automatically by the instrument.

\section{Statistical Analyses}

Data were presented as mean \pm SE. Differences of growth parameters, relative chlorophyll content, and chlorophyll fluorescence parameters among treatments were assessed with a one-way analysis of variance (ANOVA) followed by Duncan's multiple-range test in IBM SPSS statistics 23.0 software package (IBM, Chicago, USA). Significant differences were marked among treatments at the 0.05 level. Relationships between oxytetracycline content and growth parameters, leaf traits, and chlorophyll fluorescence parameters with a linear regression model. Data were log or arc-sine transformed before analysis to meet assumptions of normality and homogeneity of variance. Figures were drawn with Origin 8.5 (Origin Lab, USA).

\section{Results and Discussion}

\section{Oxytetracycline Effects on Plant Growth}

The total biomass dry weights of each rape plant showed a decreasing trend along with the increase of oxytetracycline concentrations (Fig. 1a), but oxytetracycline treatment at $10 \mathrm{mg} \mathrm{kg}^{-1}$ and $100 \mathrm{mg} \mathrm{kg}^{-1}$ showed

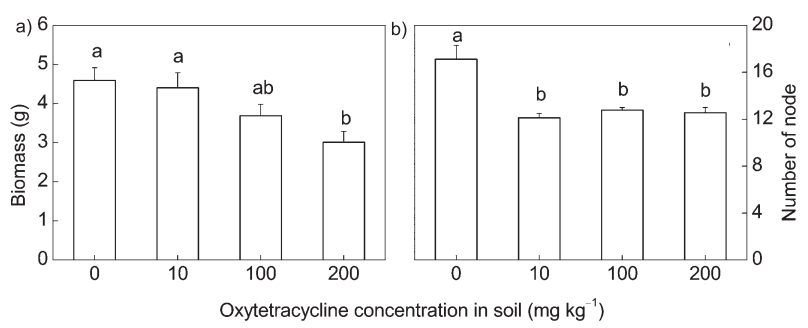

Fig. 1 Effects of oxytetracycline on biomass a) and nodes b) of rape (mean $\pm \mathrm{SE}, n=9$ ). Different letters above bars indicate significant differences $(p<0.05)$ 


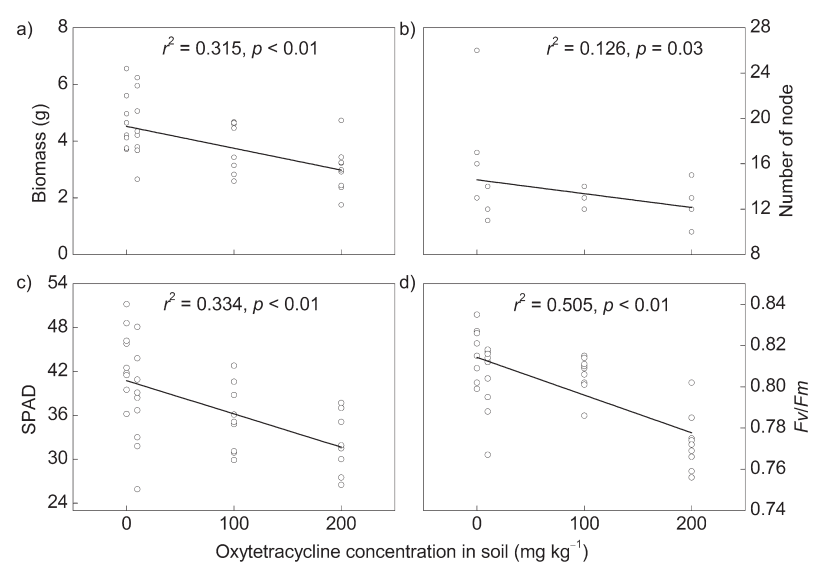

Fig. 2 Correlations fitting with linear regression between oxytetracycline concentrations and biomass a), and node number b), and relative chlorophyll content (SPAD) c), and maximum quantum yield of PSII (Fv/Fm) d) $(n=36)$.

no obvious effects on the biomass ( $p>0.05$ each). However, the plants cultured with $200 \mathrm{mg} \mathrm{kg}^{-1}$ oxytetracycline had significantly lower total biomass dry weight than that of control $(p<0.05)$, indicating that oxytetracycline exposure at high concentrations may have an inhibition effect on rape growth. Each treatment had fewer nodes than the control, but no significant differences were observed among the three treatments (Fig. 1b). Furthermore, both the biomass $\left(r^{2}=0.315, p<0.01\right)$ and node number $\left(r^{2}=0.126, p=0.03\right)$ showed negative correlations with the soil oxytetracycline contents, indicating that the oxytetracycline in soil can inhibit the biomass accumulation and node number increase (Figs 2a-b). These results are supported by previous studies, since Batchelder [16] reported that oxytetracycline could decrease the plant biomass and heights of Phaseolus vulgaris. Liu et al. [17] also reported that tetracycline and chlortetracycline have an inhibitory effect on the growth of Oryza sativa (rice). The slight inhibitory effect of tetracyclines in soil on higher plants was also unsealed in previous studies [19,31], which might be attributed to their strong adsorption onto soil components [42]. The results of the present study were in accordance with these reports.

\section{Changes in Leaf Traits after Oxytetracycline Treatment}

In this study, rape exposed to oxytetracycline at $200 \mathrm{mg} \mathrm{kg}^{-1}$ had more leaves of yellow discoloration, aging, and shedding than the control, which agrees with a number of previous studies [19-20, 43-44]. SPAD in leaves of rape were declined by $14.1 \%, 18.6 \%$, and $26.5 \%$ at $10 \mathrm{mg} \mathrm{kg}^{-1}, 100 \mathrm{mg} \mathrm{kg}^{-1}$, and $200 \mathrm{mg} \mathrm{kg}^{-1}$ oxytetracycline treatments compared to that of the control, respectively (Fig. 3a); $p<0.05$ each). The maximum quantum yields $(F v / F m)$ in rape leaves were also slightly decreased by $1.8 \%, 1.4 \%$, and $5.5 \%$ in three sequential treatment groups (Fig. 3b). Oxytetracycline exposure at different concentrations showed no effects on leaf size (including leaf length and leaf width) ( $p>0.05$; Figs $3 c-d)$.

The oxytetracycline absorbed by the plant from the root can inhibit chloroplast translation activity and chloroplast synthase activity because its chemical structure is similar to chloroplast photosynthetic enzyme [19-20], which may account for the inhibition of the photosynthetic capacity of plants. In the present study, $F v / F m$, indicating the maximum quantum yield of photosystem II, was used to assess the potential photosynthetic capacity of the plant. $F v / F m$ in rape leaf exposed to $200 \mathrm{mg} \mathrm{kg}^{-1}$ oxytetracycline was significantly lower than that of the control. Marco et al. [19] found that the treatment of Iberis sempervirens with 100 or $200 \mathrm{mg} \mathrm{L}^{-1}$ tetracycline for $30 \mathrm{~d}$ induced the decrease of chloroplast photosynthetic efficiency since photosynthetic pigment contents, including chlorophyll $a, b$, and carotenoid content, decreased significantly in the treated plants, which was also evidenced by findings of chlorotic phenotype of some treated plant leaves. A similar result has also been documented regarding the cycloheximide effect on photosynthesis of Phyllostachys edulis [45]. Other antibiotics, such as fosmidomycin, have also been found to reduce the net photosynthesis rates of both white poplar (Populus alba) and tobacco (Nicotiana tabacum) [46]. Oxytetracycline exposure at $0-200 \mathrm{mg} \mathrm{kg}^{-1}$ posed no obvious effects on the morphology of the leaves, but led to an irreversible moderate decrease in potential photosynthetic capacity of rape.

Soil oxytetracycline contents showed strongly negative correlations with $F v / F m\left(r^{2}=0.505, p<0.01\right)$, while weakly negative correlations with SPAD $\left(r^{2}=0.334, p<0.01\right.$; Figs 2c-d), revealing that the $F v / F m$ and SPAD in rape leaves could be inhibited by soil oxytetracycline (Fig. 2). The response of $F v / F m$ to adversity stress is often shown to be a very slow descending process [47].

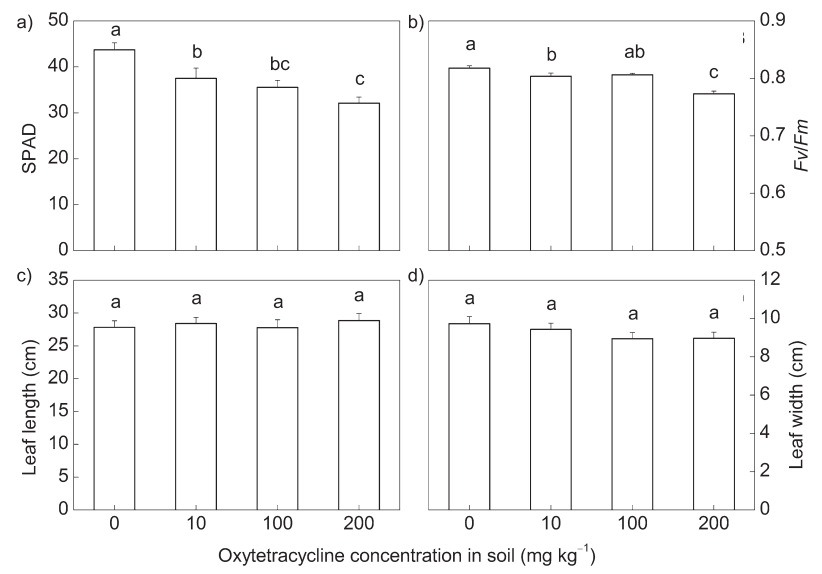

Fig. 3. Effects of oxytetracycline on relative chlorophyll content (SPAD) a), maximum quantum yield of PSII $(F v / F m)$ b), and leaf size (c and d) of rape (mean $\pm \mathrm{SE}, n=9)$. Different letters above bars indicate significant differences. 


\section{Changes of Chlorophyll Fluorescence Parameters after Oxytetracycline Treatment}

After the oxytetracycline treatment, the rape leaves had higher ETR of PSII for each treatment at higher PAR $(p<0.05$ each; Fig. 4a). Under the PAR gradients over $90 \mu \mathrm{mol}$ photons $\mathrm{m}^{-2} \mathrm{~s}^{-1}$, ETR was declined significantly due to oxytetracycline exposure in soil. The maximum ETR among the four treatments was obtained at the highest PAR $\left(1,500 \mu \mathrm{mol}\right.$ photons $\left.\mathrm{m}^{-2} \mathrm{~s}^{-1}\right)$.

Peak value of ETR will be occurring when the photosynthesis of plants reaches the saturation status. ETR will then decline, which may be accompanied by the phenomenon of light inhibition and even light damage with the PAR increase [48]. Possell et al. [46] found that the ETR in leaves of white poplar $(P$. alba) was significantly lower in fosmidomycin exposure treatments than in the control with PAR at $1,000 \mu \mathrm{mol}$ photons $\mathrm{m}^{-2} \mathrm{~s}^{-1}$. There were apparent non-stomatal inhibitions of photosynthesis, as demonstrated by the reductions of ETR in white poplar (P. alba) [46], which is similar to our findings in this study. The inhibition of ETR of PSII in rape leaves indicated that oxytetracycline exposure posed evident effects on photosynthesis capacity.

$\Phi_{\text {PSII }}$ was reduced significantly with the PAR increase in each treatment (Fig. 4b). For the control and $10 \mathrm{mg} \mathrm{kg}^{-1}$ oxytetracycline treatment, $\Phi_{\mathrm{NPQ}}$ of rape leaves increased gradually during the increasing periods of PAR from $0-1,500 \mu \mathrm{mol}$ photons $\mathrm{m}^{-2} \mathrm{~s}^{-1}$. For the other two treatments, with the PAR increase $\Phi_{\mathrm{NPQ}}$ increased gradually, and reached the maximum values at $820 \mu \mathrm{mol}$ photons $\mathrm{m}^{-2} \mathrm{~s}^{-1}$, but then sharply declined at 1,500 $\mu \mathrm{mol}$ photons $\mathrm{m}^{-2} \mathrm{~s}^{-1}$ (Fig. 4c). A continuous increasing trend was observed for $\Phi_{\mathrm{NO}}$ of rape leaves in response to the PAR increase at each oxytetracycline exposure level (Fig. 4d).

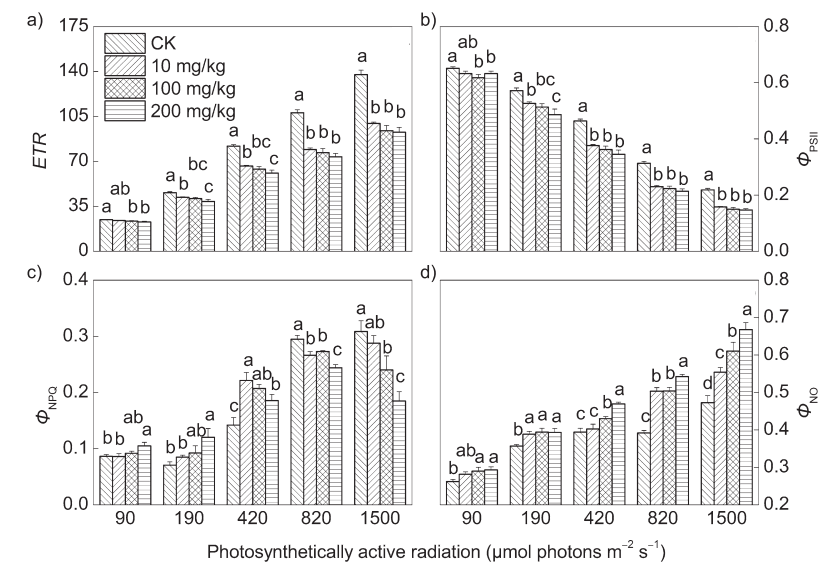

Fig. 4. Effects of oxytetracycline on electron transport rate (ETR), effective quantum yield of PSII ( $\left.\Phi_{\text {PSII }}\right)$, quantum yield of light induced non-photochemical fluorescence quenching $\left(\Phi_{\mathrm{NPQ}}\right)$, and quantum yield of non-light induced non-photochemical fluorescence quenching $\left(\Phi_{\mathrm{NO}}\right)$ of rape under different photosynthetically active radiation (mean $\pm \mathrm{SE}, n=9$ ). Different letters above bars indicate significant differences.
$\Phi_{\text {PSII }}$ means actual primary light energy captures efficiency of PSII reaction center, and can be used to quickly determine operating efficiency of plant PSII reaction center [36]. $\Phi_{\text {PSII }}$ showed a decreasing trend with the increase of soil oxytetracycline concentration under each PAR gradient, indicating that the operating efficiency of PSII reaction center in rape leaves was significantly inhibited by oxytetracycline exposure. This might be attributed to a reduction of PSII electron output caused by oxytetracycline exposure. When PAR was up to $190 \mu \mathrm{mol}$ photons $\mathrm{m}^{-2} \mathrm{~s}^{-1}$, the decline of $\Phi_{\text {PSII }}$ caused by oxytetracycline exposure was significant. With PAR over $420 \mu \mathrm{mol}$ photons $\mathrm{m}^{-2} \mathrm{~s}^{-1}, \Phi_{\text {PSII }}$ in rape leaves showed more sensitivity to oxytetracycline exposure than under the other PAR gradients according to the $F$ values in ANOVA (data not shown).

$\Phi_{\mathrm{NPQ}}$ is an important index of plant photo-protective capacity. Higher $\Phi_{\mathrm{NPQ}}$ indicates that light energy captured by plants is excessive, and redundancy excitation energy can be eliminated with a regulatory heat dissipation mechanism to avoid potential damage for the photosynthetic unit [34]. Interestingly, when PAR was below $820 \mu \mathrm{mol}$ photons $\mathrm{m}^{-2} \mathrm{~s}^{-1}, \Phi_{\mathrm{NPQ}}$ of rape leaves were significantly higher in all three treatments than in the control treatment $(p<0.05$ each), revealing that light energy captured by rape under oxytetracycline exposure was excessive, but the redundancy excitation energy still could be eliminated through heat dissipation. By contrast, when PAR was up to $820 \mu \mathrm{mol}$ photons $\mathrm{m}^{-2} \mathrm{~s}^{-1}, \Phi_{\mathrm{NPQ}}$ of rape leaves were significantly lower in the three treatments than in the control (Fig. 4c), demonstrating that photoprotective capacity of rape grown in oxytetracyclinepolluted soil was depressed. Consequently, this study showed that the light protection ability in rape leaves were significantly reduced by oxytetracycline exposure under high PAR.

$\Phi_{\mathrm{NO}}$ is a considerable index of photo-damage. The higher value of $\Phi_{\mathrm{NO}}$ indicates that light energy absorbed by the plant cannot be consumed completely through photochemical energy conversion and protective regulation mechanisms such as heat dissipation [34, 36]. Plants subjected to injury or continuous stress will lead to permanent damage to the plant's photosynthetic apparatus [34]. $\Phi_{\mathrm{NO}}$ in rape leaves was higher in the three treatments than in the control under each PAR gradient. Specifically, when PAR was up to $1,500 \mu \mathrm{mol}$ photons $\mathrm{m}^{-2} \mathrm{~s}^{-1}$, amplified differences of $\Phi_{\mathrm{NO}}$ between each oxytetracycline exposure treatment and the control were unsealed. Results showed that oxytetracycline exposure may increase the risk of injury in leaves of rape by strong light.

Subsequently, linear regression analysis was performed to characterize the relationships between the oxytetracycline concentrations and chlorophyll fluorescence parameters with amplified differences under high PAR. Fig. 5 illustrates the strong $\left(r^{2}=0.553, p<0.01\right)$ positive correlation of oxyte-tracycline concentrations with $\Phi_{\text {NO }}$, while weak $\left(r^{2}=0.435\right.$ or lower, $\left.p<0.01\right)$ negative correlation of oxytetracycline concentrations with $E T R, \Phi_{\mathrm{PSII}}$, and $\Phi_{\mathrm{NPQ}}$. 


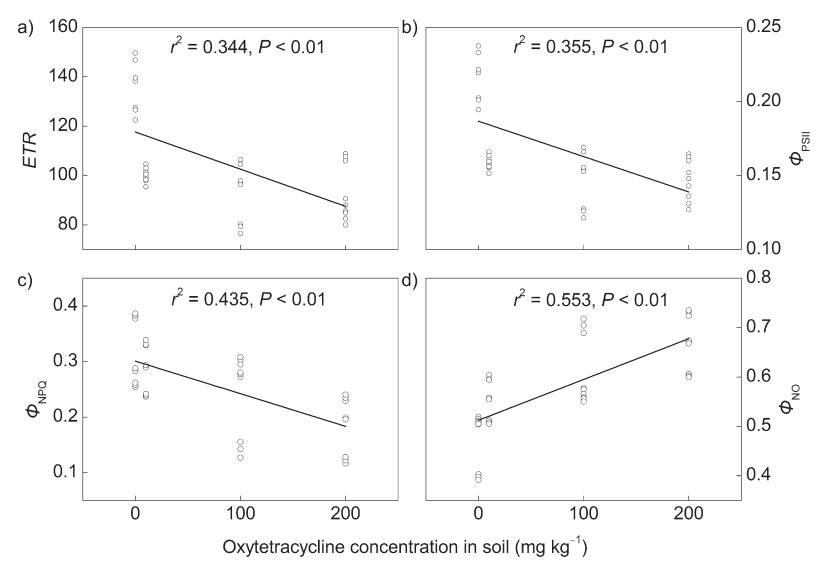

Fig. 5. Linear regression analysis of the correlations of oxytetracycline concentrations with electron transport rate (ETR), effective quantum yield of PSII ( $\left.\Phi_{\text {PSII }}\right)$, quantum yield of light induced non-photochemical fluorescence quenching $\left(\Phi_{\mathrm{NPQ}}\right)$, and quantum yield of non-light induced non-photochemical fluorescence quenching $\left(\Phi_{\mathrm{NO}}\right)$ of rape under $1500 \mu \mathrm{mol}$ photons $\mathrm{m}^{-2} \mathrm{~s}^{-1}$ photosynthetically active radiation $(n=36)$.

We suggest that signal detection of cholophyll fluorescence induced by high PAR could be used to diagnosis photosynthesis capacity changes of rape threatened by oxytetracycline exposure.

\section{Conclusions}

Oxytetracycline exposure was found to inhibit the growth, leaf relative chlorophyll content, and photosynthesis capacity of rape, and also alter the energy distribution in the photosynthetic electron transport chain. The fractions of $\Phi_{\mathrm{NO}}$ in PSII in the all-oxytetracycline treatments are especially increased with PAR increases. Photo-protective capacity and photo-damage in leaves of rape affected by oxyte-tracycline in soil to strong light were significantly changed. The present results may extend our knowledge regarding oxytetracycline effects on plant growth and development.

\section{Acknowledgements}

This study was supported by the Natural Science Foundation of Anhui Province, China (Nos. 1608085MC62 and 1608085MC64) and the Outstanding Young Talent Foundation of Anhui Province, China (No. 2013SQRL068ZD).

\section{References}

1. THIELE-BRUHN S. Pharmaceutical antibiotic compounds in soils - a review. Journal of Plant Nutrition \& Soil Science, 166 (2), 145, 2003.

2. HOMEM V., SANTOS L. Degradation and removal methods of antibiotics from aqueous matrices - a review. Journal of
Environmental Management, 92 (92), 2304, 2011.

3. BOXALLA., KRAAK G.V.D. Pharmaceuticals and personal care products in the environment, what are the big questions? Environmental Health Perspectives, 120 (9), 1221, 2012.

4. LUO Y., XU L., RYSZ M., WANG Y., ZHANG H., ALVAREZ P.J.J. Occurrence and transport of tetracycline, sulfonamide, quinolone, and macrolide antibiotics in the Haihe River Basin, China. Environmental Science \& Technology, 45 (5), 1827, 2011.

5. MEENA V.D., DOTANIYA M.L., SAHA J.K., PATRA A.K. Antibiotics and antibiotic resistant bacteria in wastewater: Impact on environment, soil microbial activity and human health. African Journal of Microbiology Research, 9 (14), 965, 2015.

6. TOPP E., CHAPMAN R., DEVERSLAMRANI M., HARTMANN A., MARTI R., MARTINLAURENT F., SABOURIN L., SCOTT A., SUMARAH M. Accelerated biodegradation of veterinary antibiotics in agricultural soil following long-term exposure, and isolation of a sulfamethazine-degrading sp. Journal of Environmental Quality, 42 (1), 173, 2013.

7. MEGRAUD F., COENEN S., VERSPORTEN A., KIST M., LOPEZ-BREA M., HIRSCHL A., ANDERSEN L. P., GOOSSENS H., GLUPCZYNSKI Y. Helicobacter pylori, resistance to antibiotics in Europe and its relationship to antibiotic consumption. Gut, 62 (1), 34, 2013.

8. WANG N., WANG Z.C., FENG G.E., JING X.U., SHAN Z.J. Environmental exposure assessment of three typical kinds of veterinary antibiotics. Journal of Ecology \& Rural Environment, 30 (1), 77, 2014.

9. MARTÍNEZ-CARBALLO E., GONZÁLEZ-BARREIRO C., SCHARF S., GANS O. Environmental monitoring study of selected veterinary antibiotics in animal manure and soils in Austria. Environmental Pollution, 148 (2), 570, 2007.

10. HAMSCHER G., SCZESNY S., HÖPER H., NAU H. Determination of persistent tetracycline residues in soil fertilized with liquid manure by high-performance liquid chromatography with electrospray ionization tandem mass spectrometry. Analytical Chemistry, 74 (7), 1509, 2002.

11. WU L., PAN X., CHEN L., HUANG Y., TENG Y., LUO Y., CHRISTIE P. Occurrence and distribution of heavy metals and tetracyclines in agricultural soils after typical land use change in east China. Environmental Science \& Pollution Research International, 20 (12), 8342, 2013.

12. HU X.G., LUO Y, ZHOU Q.X., LIN X.U. Determination of thirteen antibiotics residues in manure by solid phase extraction and high performance liquid chromatography. Chinese Journal of Analytical Chemistry, 36 (9), 1162, 2008.

13. HUANG X., LIU C., LI K., LIU F., LIAO D., LIU L., ZHU G., LIAO J. Occurrence and distribution of veterinary antibiotics and tetracycline resistance genes in farmland soils around swine feedlots in Fujian Province, China. Environmental Science \& Pollution Research, 20 (12), 9066, 2013.

14. HU X.G., ZHOU Q.X., LUO Y. Occurrence and source analysis of typical veterinary antibiotics in manure, soil, vegetables and groundwater from organic vegetable bases, northern China. Environmental Pollution, 158 (9), 2992, 2010.

15. BRAUSCH J.M., CONNORS K.A., BROOKS B.W., RAND G.M. Human pharmaceuticals in the aquatic environment: a review of recent toxicological studies and considerations for toxicity testing. Reviews of Environmental Contamination and Toxicology, 218, 1, 2012.

16. BATCHELDER A.R. Chlortetracycline and oxytetracycline effects on plant growth and development in soil systems. 
Journal of Environmental Quality, 11 (4), 675, 1982.

17. LIU F., YING G.G., TAO R., ZHAO J.L., YANG J.F., ZHAO L.F. Effects of six selected antibiotics on plant growth and soil microbial and enzymatic activities. Environmental Pollution, 157 (5), 1636, 2009.

18. LI Z J., XIE X.Y., ZHANG S.Q., LIANG Y.C. Negative effects of oxytetracycline on wheat (Triticum aestivum L.) growth, root activity, photosynthesis, and chlorophyll contents. Agricultural Sciences in China, 10 (10), 1545, 2011.

19. MARCO G.D., GISMONDI A., CANUTI L., SCIMECA M., VOLPE A., CANINI A. Tetracycline accumulates in Iberis sempervirens $\mathrm{L}$. through apoplastic transport inducing oxidative stress and growth inhibition. Plant Biology, 16 (4), 792, 2014.

20. KASAI K., KANNO T., ENDO Y., WAKASA K., TOZAWA Y. Guanosine tetra- and pentaphosphate synthase activity in chloroplasts of a higher plant: association with $70 \mathrm{~S}$ ribosomes and inhibition by tetracycline. Nucleic Acids Research, 32 (19), 5732, 2004.

21. AHMED S.E., MAHDY A.E.S. Conditions of oilseed rape cultivation in selected countries in Central Europe. Pamietnik Pulawski, 27 (11), 472, 2003.

22. MIKKOLA H., PAHKALA K., AHOKAS J. Energy consumption in barley and turnip rape cultivation for bioethanol and biodiesel (RME) production. Biomass \& Bioenergy, 35 (1), 505, 2011.

23. PIQUEMAL J., CINQUIN E., COUTON F., RONDEAU C., SEIGNORET E., DOUCET I., PERRET D., VILLEGER M.J., VINCOURT P., BLANCHARD P. Construction of an oilseed rape (Brassica napus L.) genetic map with SSR markers. Theoretical \& Applied Genetics, 111 (8), 1514, 2005.

24. BASUNANDA P., SPILLER T.H., HASAN M., GEHRINGER A., SCHONDELMAIER J., LÜHS W., FRIEDT W., SNOWDON R.J. Marker-assisted increase of genetic diversity in a double-low seed quality winter oilseed rape genetic background. Plant Breeding, 126 (6), $581,2007$.

25. SNOWDON R.J., LUY F.L.I. Potential to improve oilseed rape and canola breeding in the genomics era. Plant Breeding, 131 (131), 351, 2012.

26. ZAHN L.M. The genomic origins of rape oilseed. Science, 345 (6199), 886, 2014.

27. OLLERENSHAW J.H., LYONS T., BARNES J.D. Impacts of ozone on the growth and yield of field-grown winter oilseed rape. Environmental Pollution, 104 (1), 53, 1999.

28. SHENG X.F., XIA J.J., JIANG C.Y., HE L.Y., QIAN M. Characterization of heavy metal-resistant endophytic bacteria from rape (Brassica napus) roots and their potential in promoting the growth and lead accumulation of rape. Environmental Pollution, 156 (3), 1164, 2008.

29. TIAN L.Y., YANG J.Y., HUANG J.H. Uptake and speciation of vanadium in the rhizosphere soils of rape (Brassica juncea L.). Environmental Science \& Pollution Research, 22 (12), 9215, 2015.

30. MOURATO M.P., MOREIRA I.N., LEITÃO I., PINTO F.R., SALES J.R., MARTINS L.L. Effect of heavy metals in plants of the genus Brassica. International Journal of Molecular Sciences, 16 (8), 17975, 2015.

31. LI Z.J., XIE X.Y., ZHANG S.Q., LIANG Y.C. Wheat growth and photosynthesis as affected by oxytetracycline as a soil contaminant. Pedosphere, 21 (2), 244, 2011.

32. MAXWELL K., JOHNSON G.N. Chlorophyll fluorescence: a practical guide. Journal of Experimental Botany, 51 (345), 659, 2000.
33. GOVINDJEE. A role for a light-harvesting antenna complex of photosystem II in photoprotection. Plant Cell, 14 (8), 1663, 2002.

34. KRAMER D.M, JOHNSON G., KIIRATS O., EDWARDS G.E. New fluorescence parameters for the determination of QA redox state and excitation energy fluxes. Photosynthesis Research, 79 (2), 209, 2004.

35. BAKER N.R., HARBINSON J., KRAMER D.M. Determining the limitations and regulation of photosynthetic energy transduction in leaves. Plant Cell \& Environment, 30 (9), 1107, 2007.

36. BAKER N.R. Chlorophyll fluorescence: a probe of photosynthesis in vivo. Annual Review of Plant Biology, 59 (1), 89, 2007.

37. LIU Z., CHEN W., HE X.Y. Influence of $\mathrm{Cd}^{2+}$ on growth and chlorophyll fluorescence in a hyperaccumulator: Lonicera japonica Thunb. Journal of Plant Growth Regulation, 34, 672, 2015.

38. PAPAGEORGIOU G.C., GOVINDJEE S. Chlorophyll a fluorescence: a signature of photosynthesis. Springer-Verlag, New York, 2005.

39. ARISTILDE L., MELIS A., SPOSITO G. Inhibition of photosynthesis by a fluoroquinolone antibiotic. Environmental Science \& Technology, 44 (4), 1444, 2010.

40. GONZÁLEZ-PLEITER M., GONZALO S., RODEAPALOMARES I., LEGANÉS F., ROSAL R., BOLTES K., MARCO E., FERNÁNDEZ-PIÑAS F. Toxicity of five antibiotics and their mixtures towards photosynthetic aquatic organisms: Implications for environmental risk assessment. Water Research, 47 (6), 2050, 2013.

41. JIFON J.L., SYVERTSEN J.P., WHALEY E. Growth environment and leaf anatomy affect nondestructive estimates of chlorophyll and nitrogen in Citrus leaves. Journal of the American Society for Horticultural Science, 130 (2), 152, 2005

42. FIGUEROA R.A., MACKAY A.A. Sorption of oxytetracycline to iron oxides and iron oxide-rich soils. Environmental Science \& Technology, 39 (17), 6664, 2005.

43. KONG W.D., ZHU Y.G., LIANG Y.C., ZHANG J., SMITH F. A., YANG M. Uptake of oxytetracycline and its phytotoxicity to alfalfa (Medicago sativa L.). Environmental Pollution, 147 (1), 187, 2007.

44. TIKKANEN M., MEKALA N.R., ARO E.M. Photosystem II photoinhibition-repair cycle protects Photosystem I from irreversible damage. Biochimica Et Biophysica Acta, 1837 (1), $210,2014$.

45. GAO P., ZUO Z., WU X., GAO Y., GAO R., ZHANG R. Effects of cycloheximide on photosynthetic abilities, reflectance spectra and fluorescence emission spectra in Phyllostachys edulis. Trees, 30 (3), 719, 2015.

46. POSSELL M., RYAN A., VICKERS C.E., MULLINEAUX P.M., HEWITT C.N. Effects of fosmidomycin on plant photosynthesis as measured by gas exchange and chlorophyll fluorescence. Photosynthesis Research, 104 (1), 49, 2010.

47. SOUZA R.P., MACHADO E.C., SILVA J.A.B., LAGÔA A.M.M.A., SILVEIRA J.A.G. Photosynthetic gas exchange, chlorophyll fluorescence and some associated metabolic changes in cowpea (Vigna unguiculata) during water stress and recovery. Environmental \& Experimental Botany, 51 (1), 45, 2004.

48. FLEXAS J., BRIANTAIS J.M., CEROVIC Z., MEDRANO H., MOYA I. Steady-state and maximum chlorophyll fluorescence responses to water stress in grapevine leaves: a new remote sensing system. Remote Sensing of Environment, 73 (3), 283, 2000. 
